\title{
PIRANHAS QUE BEBEM SANGUE: TRAGÉDIA GREGA E PERMANÊNCIA EM NOSSOS SERTÕES*
}

Lorena Lopes da Costa ${ }^{1}$

Às alunas e aos alunos do curso de História da Ufopa, especialmente àqueles que, comigo, leram a Oresteia.

\section{Introdução}

No segundo semestre letivo de 2017, ofereci uma disciplina optativa para o curso de história sobre a Oresteia, única trilogia completa do teatro antigo grego que resistiu ao tempo. Ésquilo, seu autor, nasceu no século VI antes de nossa era, quando também aconteceu a primeira representação trágica de que temos notícia. Antes dele, outros nomes já se faziam conhecidos: Thespis, Pratinas, Phrynichos, dos quais nenhuma obra, porém, foi preservada.

A trilogia de Ésquilo em questão é a ganhadora do festival ateniense das Grandes Dionísias no ano 458 a.C. ${ }^{2}$ Um público composto por cidadãos atenienses, mais estrangeiros e importantes convidados, como embaixadores em passagem por Atenas, assistiram, então, à maldição da família dos Atridas, de cujo membro mais ilustre, Agamêmnon, vemos o poeta da Ilíada narrar a condução da Guerra de Troia. O público do teatro já conhece a história, enfim. A Odisseia, há séculos, a cantava:

Vede bem como os mortais acusam os deuses!

De nós (dizem) provêm as desgraças, quando são eles, pela sua loucura, que sofrem mais do que deviam!

Como agora Egisto, além do que lhe era permitido, do Atrida desposou a mulher, matando Agamêmnon

${ }^{*}$ DOI - 10.29388/978-65-86678-64-2-0-f.183-198

${ }^{1}$ Professora de Teoria da História na Universidade Federal do Oeste do Pará (Ufopa) desde 2017. Doutora em História pela Universidade Federal de Minas Gerais (UFMG), com período de pesquisa na École des Hautes Études en Sciences Sociales (EHESS). Pós-doutoranda na Universidade Federal de São Paulo (Unifesp), com período de pesquisa na Fondation Hardt.

${ }^{2}$ Nas Grandes Dionísias, vários tipos de manifestações artísticas tomavam a cena depois das libações em honra a Dioniso. Quem fazia as libações eram os militares. Observados pelo público, eles se curvavam ao teatro em favor da vida da pólis. 
à sua chegada, sabendo bem da íngreme desgraça -

pois lhe havíamos prevenido ao mandarmos

Hermes, o vigilante Matador de Argos:

que não matasse Agamêmnon nem lhe tirasse a esposa,

pois pela mão de Orestes chegaria a vingança do Atrida,

quando atingisse a idade adulta e saudades da terra sentisse.

Assim lhe falou Hermes; mas seus bons conselhos o espírito

de Egisto não convenceram. Agora pagou tudo de uma vez.

(Homero, I, v. 32-43).

O público que assiste à Oresteia de Ésquilo, ou seja, a história de Agamêmnon, de seu assassinato e do ciclo de vinganças de sua casa, já conhece a história porque conhece Homero. Mas, ainda assim, há algo novo. A tragédia não repete em novela a tradição.

Sem dúvida, trata-se de um gênero original, com características próprias e que instaura nas festividades públicas da pólis um tipo de espetáculo que trata da experiência humana, abordando algo dela que não foi abordado pela epopeia. O tema em geral, com efeito, é muito parecido; ele se mantém, sendo a maior parte das histórias, ao menos, aludidas pela poesia épica. Mas a forma de tratar o tema é distinta, porque a tragédia marca uma etapa na formação ou na percepção do homem interior, do sujeito responsável por suas escolhas, do homem trágico, enfim.

No teatro antigo, os atores vestem máscaras. Elas os transformam em heróis, integram-nos ao passado que será ali encenado. Aos olhos do público, a máscara faz o ator encarnar um desses seres excepcionais que constituíam, em função da popularidade da poesia épica, o passado de um grego — um passado distante e diferente da nova ordem da cidade, mas que permanecia vivo em algumas dimensões, como no culto dos deuses. O personagem que usa a máscara, então, é o herói em meio à cidade.

Imaginemos: em uma festa da cidade, organizada pelo arconte, com as tribos disputando prêmios, com o público escolhendo o melhor, lá está Agamêmnon, no centro do palco, voltando da guerra que lhe rendeu fama e prestes a conhecer a justiça de sua casa em forma de violência. Ele é o ontem daquela cidade inteira que lhe assiste. E é esse o ponto. O herói épico, na tragédia, deixa de ser um modelo venerado para ser um problema. Personagem, coro, autor, público entoam um debate por meio da peça. A tragédia é, por isso, a expressão das contradições que marcam o homem do período clássico, que o dividem, que o fazem questionar sua relação com seu passado e com sua cidade. 
Então, quando nós, milênios depois de sua primeira encenação, lemos a Oresteia, fica evidente o quanto suas três peças (Agamêmnon, Coéforas e Eumênides) não somente fazem um trabalho de elaboração sobre a forma de se fazer vingança e justiça, como põem em cena o enfrentamento da maneira do passado de resolver as pendências, sobretudo por meio da tradição religiosa, e o jeito moderno da pólis de resolvê-las por meio das instituições públicas, que querem, por sua vez, inaugurar uma tradição moral e humana, nova, de fato, mas incapaz de se desconectar por completo da antiga.

A pólis, então, representa-se e assiste-se: seu passado, suas contradições, suas instituições e suas dúvidas vão ao palco. No teatro, ela põe a si própria em questão. Um conhecido helenista diz, por isso, que a tragédia nasce quando se começa a olhar para o mito com os olhos de um cidadão (Vernant e Vidal-Naquet, 2001). Na epopeia, não se olha para os mitos com os olhos de cidadão. O personagem trágico começa a se perceber como agente, mais ou menos autônomo em relação aos deuses, mais ou menos senhor de seus atos, vivendo uma experiência para a qual até mesmo o vocabulário da língua grega precisaria ser elaborado. Isso, enfim, que a consciência ocidental será capaz de formular com o tempo, é, na tragédia, uma interrogação: em que medida o homem é realmente a origem, a fonte de seus atos?

É ele, o herói da guerra, um estranho, pertencente a outro tempo, desconhecedor da cidadania, da democracia, mas é ele o centro do drama. É ele o centro da atenção do público, porque, de alguma forma, ele não morreu, ele permanece no presente — aliás se tivesse morrido totalmente, não seria encenado, tampouco compreendido.

Com efeito, só conhecemos o passado quando algo dele permanece no presente. A tradição ou as tradições, arriscar-nos-íamos a dizer, com Fernand Braudel (1958, 1985), são permanências do passado, que existem como formas plásticas em outras temporalidades, inclusive no presente, porque, justamente, não se encerraram no passado. Mesmo que este seja muito diferente daquele, é preciso que algum reconhecimento exista para que se possa falar do que já não é.

Assim, se um dos objetivos da disciplina de 2017 era conhecer a Oresteia como fonte histórica, um documento de milênios de idade, para atingi-lo o caminho seria explorar nela e dela todo o material que nos permitisse pensar a vingança e a justiça no mundo grego, estabelecendo como hipótese de nosso curso que a vingança punitiva seria uma espécie de permanência da justiça em distintos tempos e sociedades. O desafio seria conectá-las, a fonte bem como essas categorias, de vingança e justiça, com o repertório dos alunos, apostando em 
sua inteligibilidade e, portanto, na permanência de parte de seu sentido. Por isso, entre as divindades que participam do enredo das peças, foram as Erínias aquelas que mereceram mais de nossa atenção.

\section{As Erínias}

Na primeira peça da trilogia, Agamêmnon, de volta à pátria, está vaidoso da guerra que fizera. Ele não só foi o líder que organizou a vingança em paga pela desonra sofrida pelo irmão (Menelau, cuja esposa havia sido levada por Páris Alexandre para Troia), como foi aquele que não mediu esforços para obter a vitória. Quando os ventos lhe impediram, a si e a seus companheiros, de prosseguir para a terra inimiga (Ésquilo, 2004a, v. 192-210) em busca de aplacar o ódio divino e cruzar os mares, sacrificou a própria filha:

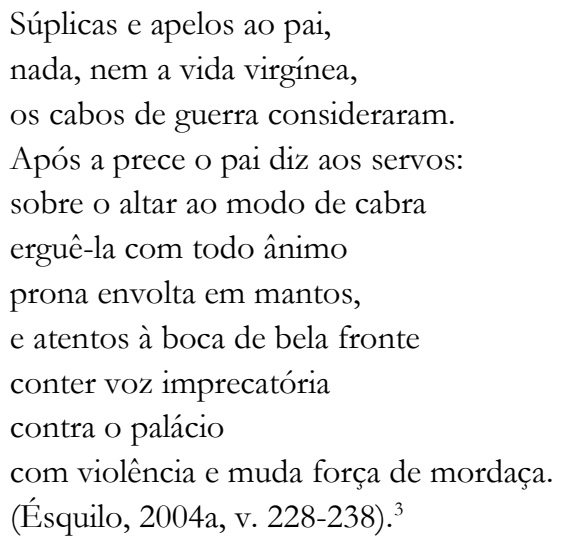

Agamêmnon, ademais do filicídio, foi o herói implacável que não se contentou com a derrota a Troia. Toda a cidade foi incendiada, seus templos foram destruídos, os homens foram exterminados, nem as crianças foram poupadas, e as mulheres entraram em escravidão. Não bastasse, desmedido, ao chegar à sua casa, pisou o tapete púrpura (Ésquilo, 2004a, v. 914-957), só oferecido aos deuses, dando então mais um motivo a seu entorno para ser punido. Todos os personagens à sua volta, mortais, divinos, homens, mulheres, vão querer vingar-se.

\footnotetext{
${ }^{3}$ As traduções utilizadas aqui para Agamêmnon, Coéforas e Eumênides serão sempre as de Jaa Torrano.
} 


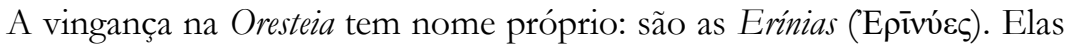

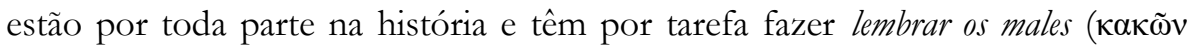
$\mu v \eta ́ \mu o v \varepsilon \varsigma$ - Ésquilo, 2013, v. 383). Representam um tipo de justiça que antecede a pólis e sua ideia de justiça democrática. Trata-se de uma justiça que depende daquele que sofreu o dolo, como a perda de um ente querido, para ser exercida. Cassandra, umas das mulheres troianas escravizadas, diz ao Coro:

\section{Confirmai se conseguindo a pista farejo vestígios dos crimes outrora perpetrados. Um coro nunca abandona esta morada consoado, não suave, pois suave não fala. Para maior ousadia, bêbado de sangue humano, o bando perdura no palácio, cortejo difícil de sair, congêneres Erínias. (Ésquilo, 2004a, v. 1184-1190).}

As Erínias atuam em bando, têm sede de morte humana e perduram no palácio do herói atrida. A trilogia narra suas ações com detalhes, mas nosso autor não está interessado apenas em apresentar essas entidades bêbadas de sangue, como fazem, contentando-se, com isso, muitos de nossos jornais. Ele quer, pelo teatro, representar a transformação das Erínias em novas entidades, as Eumênides, que dão nome à terceira das peças. Ésquilo está contando a seu público a história da Justiça e de como ela se altera com o tempo, por meio de personagens que a executam. Na primeira peça, Agamêmnon, vemos apenas a ação das Erínias, que ficam ainda mais fortes e atuantes na segunda, Coéforas. Sua justiça é a morte a se pagar com a morte. O morto paga-se com o morto. Por isso, elas gostam de sangue, embebedam-se dele, quando ele há, ou o buscam em outra fonte quando o líquido já secou.

Ésquilo não foi o único a se interessar por elas. Segundo Hesíodo, as Erínias têm sua origem do sangue do Céu. Crono, filho do Céu (Urano), ao ver os sofrimentos de sua mãe Terra (Gaia), decide com um golpe cortante mutilar a genitália do pai. Há muito, Céu, em posição constante de coito, impedia Terra de dar à luz seus filhos, não havendo nem passagem para que eles fossem expelidos, nem espaço entre Céu e Terra para que eles existissem externamente à barriga da mãe. Então, Crono, usando uma foice recurva, castra o pai, fazendo com que se espalhe pelo novo espaço criado sangue e sêmen. Do sêmen nasce a deusa Afrodite. Do sangue nascem as Erínias. Ávidas pelo caldo tinto que as gerou, daí em diante vão querer nortear as relações entre os homens. 
Assim falou. Exultou nas entranhas Terra prodigiosa, colocou-o [Crono] oculto em tocaia, pôs-lhe nas mãos a foice dentada e inculcou-lhe todo o ardil. Veio com a noite o grande Céu, ao redor da Terra desejando amor sobrepairou e estendeu-se a tudo. Da tocaia o filho alcançou com a mão esquerda, com a destra pegou a prodigiosa foice longa e dentada. E do pai o pênis ceifou com ímpeto e lançou-o a esmo para trás. Mas nada inerte escapou da mão: quantos salpicos respingaram sanguíneos a todos recebeu-os a Terra; com o girar do ano gerou as Erínias duras, os grandes Gigantes rútilos nas armas, com longas lanças nas mãos, e Ninfas chamadas Freixos sobre a terra infinita. O pênis, tão logo cortando-o com o aço atirou do continente no undoso mar, aí muito boiou na planície, ao redor branca espuma da imortal carne ejaculava-se, dela uma virgem criou-se. [...] (Hesíodo, 2007, v. 173-192).

Agora que conhecemos a origem das Erínias, voltando à nossa trilogia, vemos Agamêmnon, o herói intemperante, morrer por ação delas. Clitemnestra, com ajuda do amante (que tem também seus motivos para se vingar - Ésquilo, 2004a, v. 1577-1611), cobra a morte da filha, sacrificada pelo pai. Explicandose, ela diz ao Coro:

Tendes-me por mulher imprudente, mas eu com intrépido coração vos digo cientes: tu queres louvar-me ou repreender, dá no mesmo, eis aí Agamêmnon, meu esposo, e morto, façanha desta mão destra, justo artífice. Assim é isto. [...] Agora me condenas ao exílio do país, ódio de cidadãos e pragas clamadas do povo, outrora nada contrapuseste a este homem que desatento como da sorte de uma rês, sobejando ovelhas nos lanosos rebanhos, sacrificou a própria filha, meu dileto parto, encantador dos ventos trácios. 
A ele não devias bani-lo desta terra

punindo opulências? [...]

(Ésquilo, 2004a, v. 1401- 1420).

Se Clitemenestra não perdoa Agamêmnon, tampouco será perdoada. Na peça seguinte, a segunda da trilogia, seus filhos restantes lhe tomarão a vida como preço pela morte do pai. É que às Erínias não toca jamais descansar:
Mas sói que gotas sangrentas
vertidas no chão pedem outro
sangue: exício grita por Erínis
a trazer dos anteriores finados
outra erronia à erronia.
(Ésquilo, 2004b, v. 400-404).

Sua sede é insaciável; quanto mais sangue há, mais sangue se quer. Com senhas, sussurros, ardis, o par fraterno vai planejar a morte de Clitemenestra e de seu amante. A Orestes a mãe avisará: "Cuidado com rancorosas cadelas da mãe" (Ésquilo, 2004b, v. 924). Todavia, incapaz de se livrar das cadelas também rancorosas do pai, ele será o grande executor do novo crime punitivo.

Ora, temos aí mais uma característica importante para conhecermos as

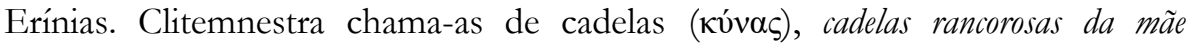

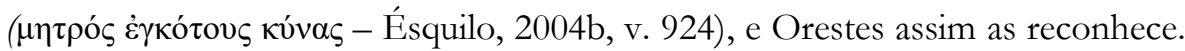
Assim que assassina a mãe, ele passa a enxergá-las e a descrevê-las: são mesmo cadelas enraivecidas, de cujos olhos goteja a seiva da vida:

11- Co: Que visões te perturbam, filho do pai?

Calma! Não temas grande vencedor.

Or: Não são visões destas minhas dores, eis claro cadelas raivosas da mãe.

Co: Novo é o sangue ainda em tuas mãos, disso provém o turvo ao teu espírito.

Or: Soberano Apolo, elas são muitas e dos olhos gotejam sangue hediondo. Co: Só tens uma purificação. Lóxias ao tocar te fará livre desses males.

Or: Ei-las, vós não as vedes, eu vejo, perseguem-me e não mais ficaria. (Ésquilo, 2004b, v. 1051-1062). 
Atordoado pelo desejo devorador das Erínias, Orestes foge para o templo sagrado de Lóxias (Apolo), deus que o incita a partir para Atenas (Ésquilo, 2013, v. 64-84). Enquanto isso, inquietas, as cadelas buscam o matricida impune por toda parte. "Sangue de mãe no chão é irreparável, ai, ai, ai" (Ésquilo, 2013, v. 260-261).

Com a saída de Orestes do palácio onde há muito o bando vingativo habitava, a história ganhará novo rumo. Em Atenas, a deusa maior vai ensinar a toda a cidade suas leis e, ao Conselho escolhido, como decidir uma sentença (Ésquilo, 2013, v. 566-575). Os homens aprenderão com os deuses que a justiça pode ser feita de outra forma, que não dente por dente ou olho por olho. Lá, o tribunal, os votos, as testemunhas, o réu passam a compor um novo tipo de cenário. Mas não é que as Erínias são deixadas para trás, como se pertencessem apenas ao passado, não é que fiquem presas ao palácio dos Atridas. Elas, se transformadas em Eumênides, continuarão a compor o cenário da Justiça. Seu furor sagrado, para tanto, deverá dar lugar à razão penal. Seu instinto violento deverá dar lugar à dimensão da palavra (Ricoeur, 2005, p. 29). O trabalho agora das cadelas divinas que antes bebiam sangue será o da vitória não maligna (Ésquilo, 2013, v. 903).

A tragédia grega serve-nos, assim, como fonte para pensar de que maneira a coletividade, ao assistir-lhe, responde às novas demandas da pólis, gerenciando o conflito que é inevitavelmente criado com o passado, uma vez que não apenas a cidade parece querer romper com seu jeito de ser no passado, como, apesar disso, ainda o vê permanecer no presente. Personagens conhecidas pelo público, restritas a "um número muito reduzido de famílias" (ov̉ $\pi \varepsilon \rho i ̀ ~$

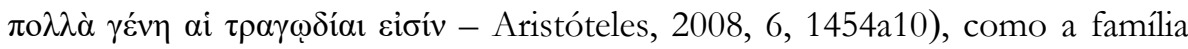
dos Atridas, extraídas de um repertório tradicional de histórias do passado, ganham vida no teatro, sendo recriadas e repensadas a cada nova encenação.

A ideia de que a tragédia retrabalha o mito e as fórmulas vindas do passado, participando da transformação do corpo cívico, que ensaia lidar com o mundo político de uma forma nova, ganha força, se pensarmos as festas religiosas — quando as peças são representadas — não exatamente como momento de pausa no cotidiano, mas como um reforço ou, ainda, como um pilar que, dando suporte ao cotidiano, experimenta com ele outra dimensão do político (ou não teria o Carnaval das Marias, Mahins, Marielles, Malês o mesmo poder?). Desse ponto de vista, a tragédia pode ser explicada, também ela, como um pilar que forma com o cotidiano do cidadão o mesmo conjunto. Os momentos de representação das tragédias devem ser encarados como episódios em que uma comunidade trabalha em público sua "estrutura mental" (ou sua "utensilagem 
mental", diria Lucien Febvre), 4 "na porção mais poderosa e também mais incerta de um mundo que ainda não tinha sido testado em suas possibilidades e seus limites" (Meier, 2004, p. 10). ${ }^{5}$ Não se trata, pois, de pensar simplesmente que a tragédia seja influenciada pela política, refletindo algumas de suas características, ou que, ao contrário, a política seja influenciada por ela, mas que, de forma mais orgânica, as representações em cena consigam trabalhar determinados aspectos da nova forma de viver (n)a pólis, a qual, exatamente por ser inédita, convive com aquilo que permanece.

\section{Erínias do sertão mineiro}

Feitas a leitura e a abordagem das peças, nossa disciplina, sem se importar com os saltos temporais, demandou aos alunos que investigassem e trouxessem para a aula fontes que, de alguma forma, respondessem à questão: as Erínias pertencem ao passado?

Dessa vez, apresentei um documento do final do século XIX da Hemeroteca Pública do Estado de Minas Gerais. ${ }^{6} \mathrm{Na}$ cidade mineira de São Francisco, em 1896, após uma briga de bar, um jagunço foi atingido por um tiro. A bala teria acertado uma das pernas da vítima, que, tendo deixado o bar, só teria sido encontrada no dia seguinte, em uma lagoa, com o corpo sem vida, o rosto esfolado e as orelhas arrancadas.

O criminoso seria, pelos testemunhos da peleja, o sobrinho do juiz local, chamado Antero Simões, que, não obstante, não teria tido a culpa apurada. Conforme o inquérito, a vítima, já embriagada, teria morrido não em decorrência do disparo, mas de um afogamento no lago somado ao ataque de piranhas, responsáveis pela mutilação do corpo. Com essa conclusão, a Justiça faria por

\footnotetext{
${ }^{4}$ A acepção proposta por Christian Meier parece aproximar-se da ideia trabalhada, não apenas por L. Febvre, mas pelos Annales de forma geral. O conceito de utensilagem mental é operacionalizado por Febvre, sobretudo em Le problème de l'incroyance an XVI ${ }^{e}$ siècle (1942).

${ }^{5}$ No original: "Et se peut-il qu'elle ait rendu des services plus essentiels encore à la 'infrastructure mentale' de ces citoyens, certes comblés de succès, mais aussi, de quelque façon, aventureux,] dans la portion la plus puissante et cependant aussi la plus incertaine d'un monde qui n'avait pas encore fait l'essai de ses possibilités et de ses limites, qui surtout se trouvait à la charnière de l'ancien et du nouveau?'.

${ }^{6}$ Conheci a presente história por meio da leitura da dissertação de mestrado de Marcela Telles Elian de Lima, defendida em 2006 na UFMG, sob orientação da professora Heloísa Starling, intitulada Pelas margens do São Francisco: a trajetória histórica e ficcional de Antônio Dó (2006).
} 
motivar na região a retomada do ciclo de vingança. Conforme registra nosso documento, a mãe da vítima diz ao magistrado encarregado do caso: "tenho fé em Deus, Dr. Antero, que as piranhas que comeram meu filho hão de comer os seus também" (O Estado de Minas, 26 ago. 1896, s. p. ). Nossa Clitemnestra do sertão avisa ao juiz que o sangue de seu filho seria a origem de mais sangue. $\mathrm{Ca}$ delas, Erínias, Piranhas, com o olfato aguçado, não tardam a levar a vingança anunciada pela mãe da vítima.

De acordo com a esposa do juiz, Amasilia Attuá, em carta escrita no dia 30 de abril de 1896, a cidade, depois do ocorrido, foi invadida por Joaquim Nunes Brasileiro e o bando dos Serranos. Os jagunços de Nunes Brasileiro cercaram a casa onde se encontrava Dr. Antero, tio do assassino, e seus dois filhos. Um deles conseguiu fugir, mas o outro morreu junto ao pai, que, "ainda agonizante (coisa horrível!!) foi esbofeteado, furaram-lhe os olhos, abriram-lhe o ventre, rejeitaram-lhe as mãos e tiraram com facas as orelhas, a língua e a pele das faces!!!" (O Estado de Minas, 26 ago. 1896, s. p.). Os corpos do juiz, de um de seus filhos e de alguns de seus aliados assassinados permaneceram insepultos, só tendo sido retirados do local da vingança executada quando o mau cheiro tornou-se insuportável. Ainda assim, apenas um dos corpos foi inumado, enquanto os outros "foram atirados ao mato para pasto dos urubus" (O Estado de Minas, 26 ago. 1896, s. p.).

\section{Erínias de outros sertões}

No dia 22/03/2019, Dilma Ferreira da Silva, de 45 anos foi assassinada no assentamento onde morava, a 70 quilômetros de Tucuruí, Pará.

Liderança importante do MAB (Movimento Atingidos por Barragens), ela foi encontrada com a garganta cortada, mãos amarradas e sinais de tortura ao lado dos corpos do marido, Claudionor Costa da Silva, e de um conhecido do casal, identificado como Hilton Lopes, de 38 anos. (Deutsche Welle, 23 mar. 2019).

Escritos e orais, os 45 documentos sobre vingança e justiça encontrados pelos alunos foram variados: ${ }^{7}$ desde uma carta de pedido de perdão ao rei no Tardo Medievo, datada do ano 1439, em busca de justiça, apresentada pelo

\footnotetext{
${ }^{7}$ Como se pode imaginar, apresento apenas alguns deles, conforme uma seleção que, se é injusta porque exclui daqui a maior parte das fontes, por outro lado é representativa da variedade mencionada de documentos, bem como da competência dos alunos para encontrá-los.
} 
aluno Gustavo Magave, a depoimentos verbais, como aquele mobilizado por Elivaldo Pinto, que, na década de 1980, então, trabalhando no garimpo do Marupá, no sudoeste paraense, testemunhou o anúncio de um crime de vendeta aos assassinos da esposa e da filha de um homem natural de Goiás. Em outros casos, a fonte impressa somou-se à oralidade, como no processo judicial de 2017, cujos autos, publicados no Diário da Justiça, foram apresentados por Letícia Almeida. Nas seis páginas do processo concernente ao crime de homicídio qualificado com erro de execução, há oito ocorrências do termo vingança ou do verbo vingar-se. Além de crimes de vingança individual, também foram mencionados crimes de vingança coletiva, seja em cidades populosas, seja em comunidades locais, destacando-se, então, a presença de vítimas indígenas e ribeirinhas.

É certo que a maior parte das fontes datou do século XX ou, ao menos, quando fontes secundárias, fez referência a eventos do século XX. Dos 45 documentos reunidos, 26 eram do século passado. Apareceram ainda 12 documentos do século atual e quatro do século XIX, estes últimos, em sua maioria, encontrados no Centro de Documentação Histórica do Baixo Amazonas (CDHBA), vinculado ao curso de história da Universidade Federal do Oeste do Pará (Ufopa). É o caso do documento apresentado pelo aluno Joanderson Caldeira, datado de 1863, descritivo da tentativa de uma escrava de envenenar seus senhores como forma de justiçamento. Também pertence ao CDHBA a fonte datada de 1906, apresentada por Denílson Reis. O processo judiciário do distrito de Itaituba, comarca de Santarém, assinado pelo juiz substituto, refere-se a quatro crimes de assassinato produzidos por Honorato Ribeiro. O primeiro deles é o homicídio da própria esposa, Josepha, conhecida como Mulher Velha, em 1904. No ano seguinte, Honorato vitima uma família sataré-maué, composta por três membros, José Muratu, sua companheira e filha, alegando punição em decorrência das injúrias que teriam sido proferidas contra sua honra.

Entre as fontes, foram comuns aquelas que identificaram redes de vingança, entendendo-as como um quadro para além do crime mencionado pelo documento. Uma nota do jornal $A$ Cidade, de Sobral, no Ceará, de 4 de outubro de 1899, encontrada pela aluna Maiara Freitas, relata o assassinato de um morador do subúrbio, agregado de um coronel. Embora breve, a nota qualifica de bárbaro o assassinato, cometido por célebres soldados (estando este último adjetivo, de fato, destacado em itálico no corpo do texto). O impresso informa ainda que a não realização do exame de corpo de delito da vítima gera a interdição de seu velório e sepultamento durante a noite que se segue ao crime, parecendo estar aí em questão a sugestão, por parte do jornal, tanto de um mecanismo de 
exercício arbitrário da violência pelos soldados citados quanto de uma proteção para a não detecção desse exercício pela delegacia local:

No dia 2 deste, pelas 4 horas da tarde, na Lagoa do Junco, suburbio d'esta cidade, os celebres soldados José Belarmino e Francisco Buretama, este, guarda municipal desta cidade, e aquelle, do corpo de segurança, assassinarão barbaramente o cidadão João Marcollino Moço, morador no pé da serra Meruoca e aggregado do Coronel José Ignacio Alves Parente. Segundo nos consta o delegado e collector José Silvestre, se negou a fazer o corpo de delicto, não obstante ter sido levado para sua casa o cadaver do infeliz Marcollino, que ficou insepulto até o dia seguinte, sem haver quem procedesse o corpo de delicto; em vista desta falta de cumprimento do dever das autoridades policiaes, o Dr. Juiz de Direito da Comarca, ordenou o sub-delegado que procedesse a corpo de delicto no cadaver do infeliz João Marcollino. (A Cidade, 4 out. 1899, s. p.). ${ }^{8}$

Por outro lado, se a notícia d' $A$ Cidade apenas inculca uma intriga de violência para além do crime aludido, ao mencionar o pertencimento da vítima ao bando de um coronel, a fonte apresentada pelo aluno Rosinaldo Garcia, dessa vez uma recente notícia de jornal, é bem mais clara, ao afirmar que, entre as famílias Dantas e Boiadeiros, a rede de vingança é uma velha conhecida na região de Batalha no estado de Alagoas, onde teria produzido, de 1999 a 2017, seis vítimas, a última sendo o vereador Adelmo Rodrigues de Melo, conhecido como Neguinho Boiadeiro. $\mathrm{O}$ assassinato ocorreu às portas da Câmara Municipal no dia 9 de novembro de 2017, a mando dos Dantas, mas, "mais do que um tradicional crime de mando em Alagoas, o caso incendiou de vez uma das rixas políticas mais conhecidas do interior do Estado" (Madeiro, 2017, s. p.).

Áudios gravados em 2018 dão novos elementos à investigação do caso. Segundo um dos advogados, um pistoleiro teria buscado a família Boiadeiro para denunciar a incumbência recebida pelos Dantas, qual seja, a de matar alguns dos inimigos, isto é, alguns Boiadeiros:

— Chegando lá, ele [o pistoleiro] me mostrou algumas conversas via WhatsApp que eram do Teobaldo, irmão da Marina Dantas [então, prefeita de Batalha], e do Ermes, chefe da segurança de Paulo Dantas [à época, deputado estadual]. Eles encomendavam a morte do meu pai, meu tio Pinto, meu primo Alexandre, o meu primo José, e o meu primo

\footnotetext{
${ }^{8}$ Todos os trechos copiados das fontes recolhidas pelos alunos respeitam a grafia do documento.
} 
Baixinho [todos Boiadeiros]. A cabeça de cada um valeria $\mathrm{R} \$ 150$ mil, só que o Adriano [o pistoleiro] me fez uma proposta que ele disse que se nós dobrássemos o valor, e ele faria o contrário: mataria Marina e Paulo Dantas. (G1 Alagoas, 10 fev. 2019, s. p.).

Com o segundo recorte de jornal, observamos a natureza das evidências dos crimes atualizar-se (nossa fonte passa a ser um áudio de WhatsApp!), à medida que se atualiza a vingança entre líderes políticos do sertão. Com efeito, essas redes de vingança podem estender-se por gerações. É que o vemos em outra das fontes, descoberta, dessa vez, pelo aluno Raimundo Bentes. Segundo o que diz seu documento, novo documento impresso, a luta política de outras duas famílias, os Alencares e os Sampaios, no sertão pernambucano, teria começado em 1710, quando quatro irmãos portugueses perseguidos pela Coroa portuguesa fixaram morada na serra do Araripe. A neta de um deles se tornaria ilustre. Bárbara de Alencar, rebelando-se contra a Coroa em 1817, veria ainda, depois de liberta, em 1824, o filho, como ela um Alencar, declarar a república na região, afrontando destarte o então governador da capitania, um Sampaio. É em 1949, contudo, com um tiroteio na cidade de Exu, que a rixa entre as duas famílias volta a produzir grande número de vítimas.

Segundo a matriarca dos Alencares entrevistada pelo jornal em questão, o Estado de S. Paulo, com o recrudescimento da rivalidade no século XX, de seu lado morrem 11 e, do lado dos Sampaios, pouco menos do que isso. Um dos sobreviventes dos Sampaios, baleado em uma emboscada em 1978, diz à reportagem ter preferido nunca revelar o nome de seu atirador: "Meu medo era ver um filho meu ir vingar a emboscada e ir matar. Preferi ser chamado de covarde a ser apontado como um homem que matou alguém" (O Estado de S. Paulo, 12 out. 2013, s. p.). Ao não identificar a vítima para não alimentar a vendeta, Jusiê Sampaio demonstra clara consciência de que um nome é capaz de despertar a sede das Erínias, ou, na metáfora de um de seus parentes, outro Sampaio: "É como se a gente vivesse perto de um vulcão adormecido. Aqui, uma palavra pode causar um impacto muito grande" (O Estado de S. Paulo, 12 out. 2013, s. p.).

Quem também se decide por tomar parte para acabar com a rivalidade dos clãs (dessa vez de forma mais ativa) é o ilustre sanfoneiro Gonzagão (19121989). Natural da região e descendente dos Alencares, o cantor era capaz de

\footnotetext{
${ }^{9}$ A reportagem apresentada pelo aluno data de 2017 e refere-se ao assassinato do vereador mencionado, ao passo que essa segunda, que dá continuidade ao caso, foi publicada apenas em 2019.
} 
reunir ali representantes dos dois lados, à maneira da deusa Atena, que, no julgamento do filho matricida de Agamêmnon, pede ao arauto para conclamar a multidão, trazendo ao Penedo de Ares assassino, Erínias, deuses, juízes e testemunhas (Ésquilo, 2013, 566-575).

\section{Considerações finais}

Recapitulando para concluir: com a trilogia de Ésquilo, acompanhamos o poeta a imaginar uma espécie de primeiro tribunal, ou, em outras palavras, imaginamos o público da pólis a ver uma encenação da criação mítica da Justiça como resposta às inesgotáveis redes de vingança corporificadas nas Erínias. Cruzando as tragédias antigas com as fontes variadas no tempo encontradas pelos alunos e pelas alunas, poderíamos arriscar-nos a dizer que a trilogia permanece atual, porque permanecemos em busca da transformação das piranhas que bebem sangue em entidades que nos protejam dessa sede que atravessa nossa tradição. Nesse sentido, fomos capazes de observar tanto a vingança como permanência na história dos homens quanto a tentativa de substituí-la por um procedimento menos violento (mesmo que possamos, junto com Paul Ricoeur, pensarmos o problema da execução da punição pela Justiça, também ele um problema filosófico) e menos dado à perpetuação. Com nossos 45 documentos, em nada gregos, mas tampouco distantes de Ésquilo, fomos levados a ressignificar a permanência na história, da qual falou Fernand Braudel. É que como força, a permanência só é, só está em atividade por ser plástica, por deformar-se, por assumir novas formas, enfim, tal como as Erínias o fazem. Ora vulcão, ora cadelas, ora piranhas, qualquer que seja sua máscara, elas permanecem em busca de sangue.

\section{Referências}

ARENDT, Hannah. Eichmann in Jerusalem: a report on the banality of evil. Nova York: Viking Press, 1963.

ARISTOTE. Poétique. Tradução: Barbara Gernez. Paris: Les Belles Lettres, 2008.

ARISTOTELIS de arte poetica liber. Edição: R. Kassel. Reimpr. de 1966. Oxford: Clarendon Press, 1968 [1965]. 
ASSASSINATO. A Cidade, Sobral: Hemeroteca Digital Brasileira, [s. p.], 4 out. 1899.

BRASIL. Processo crime distrito judiciário de Itaituba. Comarca de Santarém, pelo juiz. substituto de Itaituba. Santarém: Centro de Documentação Histórica do Baixo Amazonas - Ufopa, 25 jul. 1906.

BRASIL. TJPA. Diário da Justiça. Edição no 6.305/2017, quinta-feira, 26 out. 2017. Disponível em: < https://www.jusbrasil.com.br/diarios/165689637/ dipa-26-10-2017-pg-850 > Acesso em: 18 de abr. 2019.

BRAUDEL, Fernand. Histoire et sciences sociales: la longue durée. Annales: Économies, Sociétés, Civilisations, ano 13, n. 4, p. 725-753, 1958.

. La Méditerranée et le monde méditerranéen à l'époque de Philippe II. Paris: A. Colin, 1985. t. I.

BRAZ, Brasiliano. São Francisco: nos caminhos da história. Belo Horizonte: Lemi, 1977.

CÓLEN, Roberta. Advogado diz que família Boiadeiro tramou assassinato dos Dantas para se livrar da própria morte. G1 Alagoas, [s. p.], 10 fev. 2019. Disponível em: <https://g1.globo.com/al/alagoas/noticia/2019/02/10/advogado-dizque-familia-boiadeiro-tramou-morte-dos-dantas-para-se-livrar-da-propria-morte.ghtml> Acesso em: 9 de mar. 2019.

ÉSQUILO. Orestéia I: Agamêmnon. Tradução: Jaa Torrano. São Paulo: Iluminuras, 2004a.

. Orestéia II: Coéforas. Tradução: Jaa Torrano. São Paulo: Iluminuras, 2004 b.

2013.

. Orestéia III: Eumênides. Tradução: Jaa Torrano. São Paulo: Iluminuras,

FEBVRE, Lucien. Le problème de l'incroyance au XVT siècle: la religion de Rabelais. Paris: Albin Michel, 1942.

HESIOD. Theogony. Edição: M. L. West. Oxford: Clarendon Press, 1966.

HESÍODO. Teogonia: a origem dos deuses. Estudo e tradução: Jaa Torrano. São Paulo: Iluminuras, 2007.

HOMERI Ilias. Edição: T. W. Allen. Oxford: Clarendon Press, 1931. v. 2-3. . Edição: P. Peter von der Mühll. Basileia: Helbing \& Lichtenhahn, 
1962.

HOMERO. Ilíada. Tradução: Frederico Lourenço. São Paulo: Penguin Classics: Companhia das Letras, 2013.

. Odisseia. Tradução: Frederico Lourenço. São Paulo: Penguin Classics: Companhia das Letras, 2011.

LIMA, Marcela Telles Elian de. Pelas margens do São Francisco: a trajetória histórica e ficcional de Antônio Dó. 2006. Dissertação (Mestrado em História), Universidade Federal de Minas Gerais, Belo Horizonte, 2006.

MADEIRO, Carlos. Rixa entre famílias deixa rastro de sangue e mortes no sertão de Alagoas. UOL, Batalha e Craíbas (AL), 12 nov. 2017. Disponível em: $<$ https://noticias.uol.com.br/cotidiano/ultimas-noticias/2017/11/12/rixaentre-familias-deixa-rastro-de-sangue-e-mortes-no-sertao-de-alagoas.htm $>$ Acesso em: 22 de abr. de 2018.

MEIER, Christian. De la tragédie grecque comme art politique. Tradução do alemão: Marielle Carlier. Paris: Les Belles Lettres, 2004.

RICOEUR, Paul. Le juste, la justice et son échec. Paris: Éditions de l'Herne, 2005. . Le mal: un défi à la philosophie et à la théologie. Genebra: Éditions Labor et Fides, 2004.

TRISTEZA e medo ainda acompanham a velha Exu que Gonzagão pacificou. O Estado de S. Paulo, [s. p.], 12 out. 2013. Disponível em: < $\underline{\text { https://politica.esta- }}$ dao.com.br/noticias/geral,tristeza-e-medo-ainda-acompanham-a-velha-exuque-gonzagao-pacificou,1084782.> Acesso em: 4 de fev. 2019.

VERNANT, Jean-Pierre; VIDAL-NAQUET, Pierre. Mythe et tragédie en Grèce Ancienne. Paris: La Découverte: Syros, 2001. v. I. ; . Mythe et tragédie en Grèce Ancienne. Paris: La Découverte:

Poche, 2012. v. II. 